\title{
Legal status of the pharmacy practice in the European Union and the Republic of Macedonia
}

\author{
J. Patcheva ${ }^{1 *}$, K. Mladenovska ${ }^{2}$, L. Petrusevska Tozi ${ }^{2}$ \\ ${ }^{1}$ Pharmaceutical Chamber of Macedonia, 50-ta Divizija 34, 1000 Skopje, Macedonia \\ ${ }^{2}$ Faculty of Pharmacy, University "Ss Cyril and Methodius", Vodnjanska 17, 1000 Skopje, Macedonia
}

Received: September 2012; Accepted: November 2012

\begin{abstract}
From a historical point of view, one can notice that the role of the pharmacists employed in community and hospital pharmacies became more complex. Today, they do not only supply, store, prepare and dispense medicines with ensured quality, but they also provide professional services based on the concept of pharmaceutical care and good pharmacy practice.

In this paper, detailed review on the current legislative regulating the status and practice of the community and hospital pharmacies in some EU-member countries and in Macedonia is given. The implementation of the concept of pharmaceutical care and good pharmacy practice in selected EU member-countries, Great Britain, Germany and Slovenia, and in Croatia as a future EU member as well as in Macedonia is also discussed. In addition, set of recommendations for establishing the good pharmacy practice standards is prepared and presented. At the end, an attempt is made to establish a basis for development a modern Law on Pharmacy Practice in the Republic of Macedonia.
\end{abstract}

Keywords: good pharmacy practice, standards, legislation, EU, Macedonia

\section{Introduction}

The pharmacy profession comprises a broad area of academic and professional disciplines founded in science, business, sociology and law. During the past few decades, pharmacy, as other professions, has been changing rapidly. Until recently, the pharmacists were strictly responsible for the pharmaceutical product, production and quality control, supply, storage and dispensing to the patients at a recommendation from physicians. However, as the pharmacy industry grew and expanded, the most frequently prescribed medicines became commercially available. This situation, as well as the knowledge the pharmacists have about medicines and medicinal forms, the ways of their administration, the mechanisms in which they act and many other pharmacotherapy specific considerations

\footnotetext{
*jasminka@fk.mk
}

have allowed pharmacists to direct their attention to the patients, thus becoming an important health care provider (Pisano, 2003). One can safely say that the role of the pharmacists has shifted from preparation to dispensing of medicines, and most recently to providing professional services, a direction adopted though the concept of pharmaceutical care and clinical pharmacy (Van Mil and Schulz, 2006). The term pharmaceutical care has been firstly published in 1975. Hepler and Strand (1990) have brought this term back to life with their definition suggesting that pharmaceutical care means responsible provision of medicines in order to achieve specific outcomes that will improve the patient's quality of life. As a consequence, in the 1990s the key pharmacist organizations began to view pharmaceutical care as the pillar of their profession.

In the next few years, the concepts of pharmaceutical care and good pharmacy practice (GPP) were defined and the foundations for the application of those concepts were established. The evidence of these activities is several key 
documents, including those of the World Health Organization (WHO) and the International Pharmaceutical Federation (FIP). These documents, such as FIP: Good Pharmacy Practice in developing countries; Recommendations for step-wise approach, 1993, FIP: Standards for Quality of Pharmacy Services (in developed countries), 1993 and FIP/WHO, Annex 8: Joint FIP/WHO guidelines on good pharmacy practice: standards for quality of pharmacy services from the WHO technical report series, 2011 represented and still represent the basis for establishment and development of GPP on national level, both in developed and developing countries.

The European Union (EU) was created in 1958 by six countries in order to establish a common European market. It further expanded and since 2007 it has 27 member states and a population of half a billion people. In 2013, the number of member states will increase to 28, since Croatia will join the unified European family. The basic principles of the Union are to support free movement of goods, services, capital and citizens (Treaty establishing the European Community 2002).

The main medicines suppliers of the patients/consumers in the EU are the community pharmacies. Thus far there are not any harmonized policies covering the services of community pharmacies. There are about 400,000 community pharmacies in Europe (Pharmaceutical Group of EU - PGEU, 2011). The medicines distribution is also controlled in accordance with the supranational as well as national laws (Taylor et al., 2004). In most of the EU member countries, the community pharmacy specific laws are controlled by the governments. The EU community pharmacies are traditionally small, privately owned enterprises, operating under strict control by the state. Although there are many similarities between the laws of the different member states regarding both community and hospital pharmacy practice, the specific national laws regulating pharmacy practices and services still differ from each other greatly with respect to the health systems in the different countries.

\section{Objectives}

Having in mind, on one hand the differences in the legal status of the pharmacy practice and services in the different EU member and non-member countries, and the absence of defined GPP standards as well as a Law on Pharmacy Practice in the Republic of Macedonia on the other hand, in writing this paper, the following objectives were established: (i) to review the current legal status of the pharmacy practice in certain EU member and candidate countries; (ii) to review the national legislation regulating the pharmacy practice; (iii) to prepare a sets of recommendations for establishing GPP; and (iv) to establish a basis for preparation of a modern national Law on Pharmacy Practice.
With respect to the first objective, the review on the legal status of the pharmacy practice includes the relevant legislation of EU member countries with long traditions in pharmacy practice, high GPP standards and level and scope of clinical and pharmacy services, such as Great Britain and Germany, then a current member country, Slovenia, and a future member country, Croatia, with a level of pharmacy practice and services closest to ours, having in mind the entire and, at times, common socioeconomic development. The review on the domestic legislation includes existing laws, rule books and guidelines that regulate the pharmacy practice, which together with the existing legislation in the $\mathrm{EU}$ member countries can serve as a basis for enactment of a set of recommendations for establishing GPP standards and preparation of a modern Law on Pharmacy Practice.

\section{Legal status of the pharmacy practice in Great Britain}

The work of pharmacies in Great Britain is subject to numerous laws and other legal acts. One of the first laws that regulated the profession is the Pharmacy Act (1852), which established a system for control of the pharmacy practices by asking professionals for a registration as a chemist, druggist and/or pharmaceutical chemist. This was followed by the Pharmacy and Poisons Act (1933), which already required pharmacists to associate in a professional association, followed by the Pharmacy Act (1954), which referred only to individual pharmacists. The Health Services and Public Health Act (1968) regulates the spatial and staffing requirements for the pharmacies. The pharmacy staff in Great Britain comprises: pharmacists, pharmaceutical technical assistants, dispensary assistants and medicines counter assistants.

The Health Services and Public Health Act (1968) and Prescription Only Medicines Order (1997) are the two main legislations that cover the production, sale and use of medicines. These also cover the prescription of medicines. There are three main classes of medicines: (a) prescription only medicines - POMs which can only be procured with a prescription issued by an appropriate prescriber (for example: physician, dentist, pharmacist and in specific occasions nurse prescribers or additional prescribers); (b) pharmacy medicines - these are medicines that can be issued only in a registered pharmacy or under the supervision of a pharmacist; (c) medicines from the general sale list that can be sold in a wider variety of places without supervision of the pharmacist (for example: supermarkets).

The current Law also specifies who can and who cannot prescribe medicines. In addition, the Law allows for agreements to provide medicines to specific groups of patients under certain conditions. There are two different types of prescribers: (i) an independent prescriber is a prescriber that can prescribe medicines on his/her own from 
the British National Formulary (examples for independent prescribers include: physicians, independent nurse prescribers and independent pharmacist prescribers) and (ii) the supplementary prescriber can prescribe medicines in accordance with the clinical management plan (this plan is negotiated by the supplementary prescriber, the physician and the patient). Just as it allows pharmacists to prescribe medicines, the Law also allows physicians to dispense medicines, under regulated conditions specified in the relevant bylaws.

The National Service Act from 1977 (still in force), together with the amendments to the Health and Social Care Act (2001) provide to the health authorities in Great Britain a legal basis to organize and provide pharmacy services to patients. Thus, Article 41 of the 1977 Act is entitled: "Arrangements for pharmacy services". The services are subject to a contract whose details are negotiated by the Pharmaceutical Services Negotiating Committee - PSNC, the Department of Health - DoH and the staff from the National Health System. PSNC promotes and supports the interests of the community pharmacies that are part of the National Health System. They are recognized by the State Health Secretary as a body that represents all contractors pharmacies.

The contract (frame) of the pharmacies from the National Health System comprises three levels: (a) essential services; (b) advanced services; and (c) enhanced services. The pharmacy owners (contractors, the contract signatories for the pharmacies) have to provide the essential services, but, have also an option to provide advanced or additional services. The essential services are: dispensing, repeat dispensing, waste management, promotion of healthy lifestyle, referring patients to other health care provider, support of self-care and clinical management. The advanced services include: management of the medication use review and prescription intervention services, new medication services, appliance use review services and stoma appliance customization services. The enhanced services are a group of services provided locally upon an order from the Primary Healthcare Funds. A group of specific services of this sort were provided in England, including: small disease management, palliative care services, provision of home care, lice management services, gluten free food supply service, school services, services related to supplementary and independent pharmacist prescribing. Most of the services in this group are guided by public health aims, such as: substance abuse services, sexual health services, services related to smoking cessation, flu protection services, etc.

Hospital pharmacies are mainly regulated by three laws: (i) the Health Services and Public Health Act, which regulates the production, distribution, export, import, sales and supply of medical products, (ii) the Medicine Abuse Regulations; and (iii) the Pharmacy Act. The Health Services and Public Health Act (1968) specify that certain activities are legal when done in a hospital or by the hospi- tal staff. The following activities may be done by or under supervision of a pharmacist in a hospital: (i) preparation of medicine in accordance with a prescription given by a practitioner; (ii) dispensing of medicine in accordance with a prescription given by a practitioner; (iii) assembling a medicine; and (iv) preparing a stock of medicines with a review to dispense them in accordance with a prescription given by a practitioner.

About 6,000 pharmacists work in hospitals in Great Britain. Most of them work in hospitals that are a part of the National Health System, but some work in the private sector. Data on the operation of hospital pharmacies and hospital pharmacists are included in the reports of the European Association of Hospital Pharmacies. They state that the pharmacists that work in hospital pharmacies in Great Britain shall be required to have the same education profile as the pharmacists that work in community pharmacies. However, most of the hospital pharmacists acquire an even higher level of education, for example the pharmacists finish graduate studies in clinical pharmacy or specialize in hospital pharmacy. The Health Services and Public Health Act do not require the hospitals to have a registered pharmacy nor to employ a pharmacist. However, the policy of the National Health System is such that it requires the pharmacist to provide safe and efficient medicine management system in the entire hospital, although not obligatory responsible for the supply of medicines. According, to the same source, European Association of Hospital Pharmacies, more and more pharmacists spend their time on hospital wards, including time spent on rounds, monitoring what has been prescribed and advising the nurses and the physicians on the safe use of medicines. The hospital pharmacies in Great Britain have developed their clinical activities with a view of providing patient with the maximum benefit from the treatment at least possible costs.

\section{Legal status of the pharmacy practice in Germany}

In Germany there are several legal acts that regulate the profession, pharmacies and medicines: The Medicinal Products Act (Gerzets über Medizinprodukte, Federal Law Gazette from 12.12.2005, as amended on 28.9.2009), the German Pharmacies Act (Gezets über das Apotenkenwesen, Federal Law Gazette from 15.10.1980, as amended on 28.5.2008) and the Ordinance on the Operation of Pharmacies (Apotekenbetriebbsordnung - ApBetrO, Federal Law Gazette from 9.2.1987, as amended on 2.12. 2008).

The Medicinal Products Act (2005) regulates the medicines and their marketing. What this Law prescribes regarding the requirements for medicines, the production of medicines, the procedure for marketing authorization of medicines and other requirements is in accordance with the European legislation, especially the Directive 2001/83/ EC. The German Pharmacies Act regulates that "the phar- 
macies shall be responsible to provide appropriate medicinal products to the population as required by public interest and individuals intending to operate a pharmacy and up to three subsidiary pharmacies should require permission from the relevant authority" (Article 1).

The operations of hospital pharmacies, military pharmacies, pharmacy subsidiaries and the emergency pharmacies are regulated in the second chapter of the German Pharmacies Act. Upon application, the sponsoring institution for a hospital must be granted a permission to operate a hospital pharmacy if: (i) employs a pharmacist that fulfills the same requirements as for working in a community pharmacy and (ii) proves that the hospital pharmacy requirements prescribed in the Ordinance on the Operation of Pharmacies (Article 14, Item 1, Paragraph 1) have been fulfilled. The manager of the hospital pharmacy or the pharmacist commissioned by him/her must inform and consult the hospital's physicians on the medicines, especially with regard to the purposeful and economical medicinal treatment (Article 14, Item 1, Paragraph 2). The hospital pharmacy can acquire a license to supply another hospital by signing a written contract (Article 14, Item 3).

The third section of this Act regulates the Ordinance on Operation of Pharmacies $(1987 ; 2008)$. It is stated that the pharmacies in Germany can employ pharmaceutical and non-pharmaceutical staff on positions compatible with their education and knowledge. The pharmacy staff comprises: pharmacists, individuals in training to become a pharmacist, pharmaceutical-technical assistants, individuals in training to become a pharmaceutical-technical assistant, assistant pharmacists, pharmaceutical engineers, individuals in training to become a pharmaceutical engineers, pharmacy assistants and pharmaceutical assistants. Nonpharmaceutical staff includes in particular pharmacy aides, skilled pharmacy workers and pharmaceutical-commercial employees that, within the pharmaceutical activities, assist the pharmacy staff in preparation and testing of pharmaceuticals (Article 3).

Pharmaceutical activities in accordance with this Ordinance shall include development, preparation, testing and dispensing of pharmaceuticals, information and advice on pharmaceuticals as well as checking of pharmaceutical inventories (in hospitals) (Article 3, Paragraph 4). Persons that are not part of the pharmacy staff shall be forbidden from performing pharmacy activities (Article 3, Paragraph 5). The person performing pharmacy activities has to have an excellent command of the German language (Article 3, Paragraph 5). The type, size, number, location and equipment of the premises are regulated in Article 4 and they must be suitable for the operation of the pharmacy.

Germany allows the purchase and dispensing of the medicines prescribed by a veterinarian and this is regulated in Article 19.

The pharmacist must inform and advise customers and individuals entitled to practice medicine, dentistry or veterinary medicine as far as this is required for reasons of drug safety. The managing pharmacist of a hospital-supplying pharmacy or the pharmacist authorized by him/her must inform and advise the physicians of the hospital on pharmaceuticals. He/she is a member of the Hospital Drug Commission (Article 20, Paragraph 1). Article 21 regulates the management of the medicines risk and the risk of non-marketable medicines (for example: withdrawn medicines). Maintaining proper records is one of the most important things in the modern pharmacy operations and it is regulated in Article 22.

Articles 26 to 33 regulate the operations of hospital pharmacies, while Articles 34 to 37 specify the penalty provisions. Hospital pharmacies are a functional part of hospitals, responsible for proper supply of one or more hospitals with medicines (Article 26, Paragraph 1). The pharmacist responsible for maintaining the pharmacy should check the stored medicinal products (Article 32). The hospital pharmacies are required to provide for additional working hours (stand by duty) in order to ensure the proper supply of the hospital with medicines (Article 33).

The community pharmacies in Germany, in addition to medicinal products can also sell parts, information objects or media that directly or indirectly help or promote the health of people or animals, testing chemicals, chemicals, laboratory reagents, parts and objects for personal hygiene and body care, pesticides and plant protection agents and products used in the growing of animals.

\section{Legal status of the pharmacy practice in Slovenia}

The pharmacy practice in Slovenia is regulated in several laws and bylaws: the Law on Healthcare (Zakon o zdravstveni dejavnosti, Official Gazette of RS 23/2005 as currently amended), the Law on Pharmacy Practice (Zakon o lekarniški dejavnosti, Official Gazette of RS 36/2004 as currently amended), the Law on Health Insurance (Zakon o zdravstvenem varstvu in zdravstvenem zavarovanju, Official Gazette of RS 72/2006 as currently amended) and the Rule Book on Pharmacy Practice (Pravilnik o pogojih za opravljanje ljekarniške dejavnosti, Official Gazette of RS 36/2004).

The only reference to the pharmacy practice in the Law on Healthcare (36/2004) is made in Article 20 where it states that "the pharmacy activities shall be regulated by a separate law". Therefore, the pharmacy practice is comprehensively included in the Law on Pharmacy Practice (36/2004). Article 1 and 2 of this Law define the pharmacy practice as a part of the healthcare and public service performed by public institutions and the individual concessioners in the pharmacies and their subsidiaries, and that, in addition to supplying population with medicines, they also supply medical devices and veterinary medicines, prepare and control medicines and medical devices, provide advice on use of medicines at the moment of dispensing. Articles $5,6,7$ and 8 suggest that the pharmacies should fulfill spe- 
cific requirements with respect to premises, equipment and staff. These requirements are regulated in more detail in the Rule Book on pharmacy practice. The second part of this Law defines the public institute as an organization of pharmacies and their subsidiaries as its organizational units that perform pharmacy practice (Article 10), managed by a council (Article 11) that elects a director (Article 12) who manages the organization. The third part of the Law defines concessions as an opportunity to open a pharmacy and perform pharmacy practice. The fourth part of the Law refers to the subsidiaries of pharmacies that can work only under the supervision of the pharmacy to which they belong (Article 21). The fifth part refers to hospital pharmacies. This Law also addresses the working hours, supervision, association within a Pharmaceutical Chamber as well as penalty provisions for non-compliance with the provisions of this Law.

The Rule Book for pharmacy practice (36/2004) explains in more detail everything that is regulated in the Law on Pharmacy Practice (36/2004). Thus, Article 1 states that "this Rule Book shall determine the requirements that the staff, premises, equipment, reference literature, the record keeping and method for registration of a pharmacy must fulfill". Pharmacy activities take place in hospital pharmacies, as well as in their organizational parts (Article 1). The hospital pharmacy is an organizational unit of the hospital responsible for supplying the hospital with medicines and medicinal products for treatment and care of hospitalized persons (Article 2, Item 1). In addition, pharmaceutical care has been defined as a "responsible provision of therapy to achieve a positive final outcome with a view of optimizing the quality of life of the patient" (Article 2, Item 3). Article 3 of this Rule Book contains the services that can be provided by the pharmacy. There are total of 32 services in addition to preparation and dispensing of medicines and medical devices, preparation, control and dispensing of magistral products and homeopathic medicines. The pharmacy can also provide record keeping on medicines for future audit and inspection, advices and information with reference to medicines and medical devices and pharmaceutical care. The hospital pharmacists are allowed/ encouraged to participate in clinical trials and pharmacy and therapeutic committees.

The second part of the Rule Book contains the requirements that the pharmacies have to fulfill. First it describes the external, physical characteristics that a pharmacy should have, in particular that a pharmacy has to be appropriately marked, so they could be visible and distinct from other shops. With respect to the staff, it states that the pharmacy shall be managed by responsible pharmacist (Article 6). The rooms within the pharmacy must be distributed and equipped in a manner that will satisfy the quality requirements in accordance with the Good Pharmacy Practice (Article 8, Paragraph 1). The pharmacy must have, in its premises, written or electronically available reference literature as a source of information and advice on the med- icines and for the purposes of preparation of good quality products (Article 22). Within the scope of its work, the pharmacy must keep records (documentation) for medications.

A hospital pharmacy must have at least the following areas: (i) medicine reception, (ii) medicine dispensing area, (iii) medicine storage area, (iv) toolkit washing area, (v) administration area and (vi) toilets and wardrobe (Article 11). The total surface areas for a special hospital, general hospital and a clinic and institute, respectively, are specified in Article 11. A hospital ward pharmacy that organizes the preparation of particular pharmaceutical forms must also have an area: (i) for preparation and (ii) for washing the toolkits (Article 12, Paragraph 3).

\section{Legal status of the pharmacy practice in Croatia}

Pharmacists and the pharmacy practice in the Croatian legislation can be found in several laws and other legislative acts, but mainly in the Law on Healthcare (Zakon o zdravstvenoj zaštiti, 150/08 with all its amendments), the Law on Medicines (Zakon o ljekovima, 71/07 with all its amendments), the Law on Pharmacy (Zakon o ljekarništvu, 121/03 with all its amendments), the Law on Mandatory Health Insurance (Zakon o obaveznoma zdravstvenom osiguranju, 150/08 with all its amendments) and the Rule Book on the Conditions under which a Pharmacy can be Opened (26/07).

The Law on Healthcare (150/08), Article 26, Paragraph 1, which stipulates everything that is included under primary healthcare, also states "supply and preparation of medicines and supply of medicinal products (line 17)", and Paragraph 2, which stipulates the primary healthcare activities, also states "pharmacy practice (line 15)". This Law, section VII, under the title "Healthcare institution", Article 78 states that the healthcare institution, among other things, shall also perform pharmacy practice. In addition, Chapter VIII Secondary Healthcare Institutions, under the title Hospital, Article 88 states that "among other things, the organization shall also supply medicines and other medicinal products".

In the Law on Medicines (71/07), with reference to the pharmacy practice and regarding the dispensing of medicines and patient related services, only the Article 65 regulates the retailing of medicines and their marketing. However, the pharmacy practice and pharmacies are most comprehensively regulated in the Law on Pharmacy (121/03), which regulates the method of organizing and implementing pharmacy practice as a part of the healthcare system, performed as a public activity by pharmacists (Article 1). The second section of this Law addresses and regulates the pharmacy practice, supply and preparation of medicines as well as supply of the population, healthcare institutions, other legal entities and private practice healthcare workers with medicinal products (Article 1). However, Article 
5, Paragraph 1 states that "in addition to supply of medicines (Article 2) there is also supply of homeopathic products, food for children, dietary products, cosmetic and other health protecting agents and also advising on prescription or the proper administration of medicines, homeopathic and dietary products". The pharmacy activities are performed by masters of pharmacy in cooperation with other health workers. They implement pharmaceutical care in order to achieve a better outcome from the pharmacotherapy, to promote rational use of medicines and medicinal products and actively to participate in the prevention of diseases and health protection (Article 6, Paragraph 1). The pharmaceutical care in accordance with this Law includes rationalization of the treatment costs, promotion of the treatment procedures and objectives, monitoring, avoidance or reduction of adverse drug reactions, avoidance of interactions, double therapy or allergies, care for patients' compliance, improvement of the clinical treatment outcomes and implementation of preventive measures for health preservation and protection (Article 6). The third section of this Law regulates the establishment and organization of the pharmacy practice and states that the pharmacy activities shall be performed within an established network of healthcare in accordance with a special law (Article 7, Paragraph 1).This part also regulates that the activities have to be performed at a primary, secondary and tertiary level (Article 7, Paragraph 2). The activities would be performed in pharmacies and depots, and only partly in galenic laboratories for verifying the quality of the galenic preparations and identification of active substances (Article 8). Hospital pharmacies are regulated in Article 10 where it states that "the hospital pharmacy shall ensure the supply of hospital healthcare institutions with medicines and medicinal products necessary for the hospital activities". The galenic laboratory is regulated in Article 11, while the laboratory for controlling the quality of the galenic preparations and identification of active substances is in article 12 . In section seven, this Law also regulates another important operational segment and that is documentation. Expert supervision over the work of the pharmacies, the laboratories, and the masters of pharmacy will be performed by the Chamber (Section 8).

Another legal act important for the regulation of pharmacy operations in Croatia is the Rule Book on the Requirements for the area where a pharmacy can be opened $(26 / 07)$. The conditions that determine the area are the number of persons with mandatory health insurance and the distance between pharmacies (Article 2).

\section{Legal status of the pharmacy practice in the Republic of Macedonia}

The pharmacies and the pharmacy practice in Macedonia are regulated in several laws and bylaws. One of them is the Law on Health Protection (Закон за здравствената заштита, 43/2012 from 29.03.2012). This Law is relatively new and substantively differs from the previous Law (1997), in particular with reference to the establishment of the healthcare system and the provision of healthcare services. The Law is currently being implemented and the bylaws are being enacted. The Law offers to some extent a slight improvement over the previous one. It defines pharmacy activities, which are broader, and addresses the entire field of operation of the pharmacists as it is required by the GPP guidelines. It has a new and expanded definition of a pharmacy as a healthcare institution.

Another Law that regulates the pharmacy activities is the Law on Medicines and Medical Devices (Закон за лековите и медицинските помагала, 106/2007, 88/2010, $36 / 2011,53 / 2011,136 / 2011)$. It regulates the medicines and medical devices that are used in human medicine, the conditions and the method of assuring their quality, safety and efficiency, the method and procedure of production, testing, marketing, formation of prices, quality control, inspection and supervision, which is largely in accordance with the European regulations i.e. the Directive for Medical Products for Human Use (2001/83/EC). According to the Article 13 of this Law, medicines can be classified according to the place and manner of dispensing as: (i) medicines dispensed only with a prescription; (ii) medicines dispensed without a prescription; and (iii) medicines dispensed only in a healthcare institution. Medicines dispensed without prescription are medicines with a broad spectrum of therapeutic indications, low toxicity, low possibility of overdosing, insignificant interactions, well known indications for the patients and appropriate for selftreatment (Article 12, paragraph 2). The third section of this Law regulates the marketing of medicines. Article 81 stipulates that "the medicines will be retailed in pharmacies" (Paragraph 1), that "the retailing shall mean supply, storage, keeping and dispensing of medicines" (Paragraph 2) and that "a pharmacy shall be a legal entity that shall be established and operate in accordance with this Law (Paragraph 3) and the Law on Health Protection" (previously stated). The Law on Medicines and the Law on Health Protection requires the pharmacies to fulfill appropriate conditions: have appropriate premises, equipment and staff, have an appropriate number of employees with higher education in the area of pharmacy and with secondary education in the area of pharmacy. The Law on Medicines further regulates that "the pharmacy shall keep appropriate records of the consumption of medicines, introduce a system of quality and an organized work flow in accordance with the principles of good pharmacy practice and fulfill the obligations of a public service i.e. the obligation to guarantee continuous and appropriate variety and quantity of medicines in order to meet the needs of the patients in a specific geographic area" (Article 82). Article 82, the last paragraph also stipulates that "the Minister of Health shall enact a manual on the principles of good pharmacy practices". 
Pursuant to this Law (Article 13, Paragraph 4), the Rule Book on the method of dispensation of prescription medicines (106/07) was enacted. This Rule Book regulates the method of prescribing and dispensing of the medicines. It is strictly forbidden to dispense prescription medicines without a prescription, a provision which is not completely enforced in the Republic of Macedonia.

Another Law that has provisions that regulate pharmacy activities is the Law on Health Insurance (Закон за здравственото осигурување, 25/2000 with all its amendments), which regulates the health insurance of citizens, the rights and obligations arising from the health insurance as well as the way of implementing health insurance (Article 1). According to this Law, the list of basic services covered by the Health Insurance Fund also contains medicines in accordance with the list of medicines which is determine by a general Act enacted by the Health Insurance Fund, agreed by the Minister of Health (Article 9, Item 8) and approved by the Commission from the Government of the Republic of Macedonia (Article 9-a, Paragraph 2). The Health Insurance Fund is the only one state owned purchaser of health services on behalf of the insured persons (Article 68 - a, Paragraph 1) and, depending on the need for healthcare services and the allocated funds for that purpose in the budget of the Fund, it signs or terminates contracts with healthcare institutions i.e. pharmacies (Article 68-a, Paragraph 2). Currently, the Fund pays to the pharmacies only for the service of supplying and dispensing of medicines. Pursuant to several different articles in the Law on Health Insurance, the management board of the Health Insurance Fund of Macedonia enacted a Rule Book (2000) on the content and method of administering the rights and obligations arising from the mandatory health insurance. This Rule Book also regulates the use of medicines (Section 8). The form for dispensing medicines covered by the Fund is different from the form for medicines regulated by the Rule Book on the method of dispensing of prescription medicines (106/07) enacted in accordance with the Law on Medicines and Medical Devices (106/2007).

The Government of the Republic of Macedonia, in accordance with the Law on Health Protection enacts health programs like the Health for All Program (2011) where pharmacists are not directly involved. There is no legislatively mandated or contractual obligation for the pharmacists to be included in such programs with their services.

\section{Recommendations for establishing GPP standards in the Republic of Macedonia}

Considering the pharmacy legislation, pharmacy activities, services provided by the pharmacists and the role of the pharmacists in the health protection and prevention from diseases, establishing a concept of GPP according to the latest joint FIP/WHO Guidelines for GPP: Standards for quality of pharmacy services (2011) would be of great importance. This Guideline states that "when establishing minimum GPP standards, it is important first to define the roles of the pharmacists, as expected by the patients and society. Secondly, relevant functions for which pharmacists have direct responsibility and accountability need to be determined within each role. Thirdly, minimum national standards should then be established in a set of activities supporting each role in order to satisfy the needs of the people and society. As the Guideline state, the minimum national standards for each activity are based on processes that need to be relevant and defined appropriately according to the local needs for pharmacy practice and national profession aspirations. It would be good to review the roles of the pharmacists and accordingly, the activities and needs, the minimal national standards setup in the Guideline, our national legislation and environment in which the pharmacists work and to discuss what would be recommendable to change and amend.

According to the Guideline, the first role of the pharmacists is to prepare, obtain, store, secure, distribute, administer, dispense and dispose medicinal products. This role entails the preparation of extemporaneous medicinal preparations and products for which the minimum required standards are related to requirements regarding premises and providing consistent preparations in accordance with prescription standards and formulas, quality standards for raw materials, equipment and preparation processes. These requirements have been regulated in the current regulative in the Republic of Macedonia. Another function of pharmacist is to obtain, store and secure medicinal preparations and products. This function is also regulated in Macedonia. However, it needs to be augmented with several provisions that will ensure quality of supply from the point of view of transparency and avoidance of entry of substandard, low quality, unapproved, fake or falsified medicines. The EU has enacted a Directive 2011/62/EU that regulates this issue. Currently, the Directive is being implemented in the national legislations of the EU member states. In addition, provisions should be enacted that will regulate the information system that will support the roles, functions and activities of the pharmacists. Great Britain, Germany, Slovenia and Croatia have such systems, whereas in Macedonia it is still in the pilot stage. The third function is distribution of medicinal preparations and products. Minimum national standards should be established for these activities. The minimum national standards in this respect have been implemented in Macedonia, especially in the Law on Medicines and Medical Devices. The only thing that could be strengthened concerns the establishment of an efficient system for recalling of medicines that are known or suspected to be unapproved, fake or falsified and to prepare a strategy for disaster or pandemic preparedness.

The fourth function is the administration of medicines, vaccines and other injectable medications. This function requires appropriate education and training of the pharmacists, suitable premises and procedures. This function is 
regulated and implemented only in several European countries, such as Portugal. Nevertheless, the other countries undertake activities to regulate and implement this function. It is recommendable to introduce and functionally implement this function in Macedonia as well. The fifth function is dispensing of medicinal products. The dispensing of medicines is regulated in Macedonia, but it requires some amendments. It is necessary to enact procedures for this function and to provide discretion in the space where medicines are dispensed and advice is given at the time of dispensing, having in mind, the provisions stipulated in the Law on personal data. The sixth function is disposition of medicines. With respect to what could be done in Macedonia, some amendments regarding this issue should be provided such as the procedures that should be enacted for the previous function.

The second role that the pharmacists must have is to provide efficient therapy management. According to the Guideline, the first function of this role is the assessment of the health status and the needs of the patient. This role has been recognized in Great Britain. In Germany, Croatia and Slovenia, it is present in the secondary legislation arising from their national pharmacy laws/acts. In Macedonia this is not regulated by law or by any other regulation. If a Law on Pharmacy Practice is drafted and enacted, it would be good if this function is defined there or in the secondary legislation arising from the Law.

The second function of this role is management of patient medication therapy. This function entails access to an appropriate evidence base related to the safe, rational and cost-effective use of medicines such as reference books and scientific literature, then having a key role in educating prescribers on the access to and evidence for optimal and appropriate use of medicines, use of clinical data and patient data for therapy adjustment, as well as enactment of procedures for referral of the patients to other health workers and provision of healthcare continuity. The legislation in the countries reviewed by this paper regulates this function, while in Macedonia this function is not regulated. However, it could be regulated if a Law on Pharmacy Practice is enacted. The third function is monitoring of patient progress and outcomes. This function, in addition to requiring patient dedication, also requires record keeping. In Germany, Slovenia and Croatia this function is regulated in their primary and secondary legislation on pharmacy practice, and in Great Britain it is regulated in the contracts signed by the pharmacies. This function should be regulated in Macedonia as well. The fourth function is provision of information on medicines and health-related issues. This function exists in the legislations of each of the mentioned countries, as part of the definition of pharmacy practice. In Macedonia, this function should be included in the law(s), rule book(s) and regulation(s).

The third role that the pharmacists have to have is maintenance and improvement of professional performance through the function for planning and implementa- tion of strategies for continuous professional development. This role has been recognized and much effort for implementation is done in Macedonia.

The fourth role is contributing to the improvement of the efficiency of the healthcare system and public health through the functions of dissemination of evaluated information on medicines and various aspects of self-care, engagement in preventive care activities and services, compliance with national professional obligations, guidelines and legislations and advocating and supporting national policies that promote improved health outcomes. The information aspect has not been addressed or regulated in Macedonia, unlike the other countries mentioned here, where the information aspect is one of the most recognized and first defined function of the pharmacists. As was previously stated, the pharmacists are not mentioned in the prevention activities that promote public health and disease prevention. Certainly, with respect to this function and the function of advocating and supporting national policies, the pharmacists in Macedonia have to be more active and demanding through their associations or on their own.

\section{Basis for drafting a modern national Law on Pharmacy Practice}

One important document for the healthcare sector in the Republic of Macedonia is "Health Strategy of the Republic of Macedonia 2020, a safe, efficient and fair health system" (2007). This document provides a snapshot of the healthcare system at the time together with the demographic and social aspects and needs of the population and the country. It also gives recommendations on what should be done to promote the healthcare system, to raise the level and scope of the services (including pharmacy) and, at the same time, to rationalize the functionality and reduce costs. The enactment of this document is of a great importance to the entire health system and in particular to the pharmacy sector. The weaknesses in pharmacy practice were identified and recommendations given as to what to do in the future. Part of these recommendations brought positive results such as: review of the positive list, the list of medicines covered by the Health Insurance Fund, which should be reviewed more frequently in order to provide better medicines and to increase availability of the medicines to specific categories of patients. Very important, the concept of "pharmaceutical care" was mentioned for the first time and it was stated that a transformation of operations is required, which would entail enactment of appropriate guidelines for GPP that will contain the national standards as well. It also states that models need to be developed for providing pharmaceutical care at all levels of healthcare, including the recognition of the roles of pharmacists in accordance with the GPP standards.

The Green Book (2009), need to establish GPP standards in accordance with the latest FIP/WHO Guideline, 
the needs for transformation imposed globally and the national needs are a good basis for enacting a Law on Pharmacy or Pharmacy Practice in the Republic of Macedonia. There are numerous reasons for enacting such a Law. One of them is certainly Macedonia's aspiration to enter the European Union and the trend in the EU regarding approximation of the national regulative framework. Another incentive to pass such a Law is the existence of such laws in the EU countries and not only in the countries with long traditions and high GPP standards such as Great Britain and Germany. Looking at the Laws and the Rule Books arising from it in Slovenia and Croatia, one can notice that the legislation contains most of the required provisions for pharmacy practice, services, spatial and staffing requirements, based on the concept of pharmaceutical care and GPP and the national socioeconomic needs to establish and maintain a modern health system focused primarily on the health of the population. Certainly, in addition to the experiences of the other countries, the drafting of a legislation of this kind would also require a broader examination of the current situation in the pharmacy sector in Macedonia. This will help to identify the weaknesses in order to overcome them and will also help to guide the process of drafting and enacting the legislation.

The benefits from having a Law on Pharmacy (Practice) are numerous. This will benefit the pharmacists, because they will be more recognizable, more involved, they will use their knowledge and skills better, and they will be more engrossed in the provision of health to the population. Society will get better quality, economically more favorable services, the health system will be more efficient, better and the savings will be greater, primarily due to better prevention. The biggest benefit will be that of the population, in particular the patients. They will get a better, more efficient and more acceptable system of services.

\section{Conclusion}

The review on the regulations regarding pharmacy practice and services in Great Britain, Germany, Slovenia and Croatia suggests that there are differences in the regulation of the individual segments of the pharmacy practice. For example, there are small differences in the requirements for opening new pharmacies. There are differences in the definition of the roles of the staff in the pharmacies which, primarily, do not refer to the pharmacists with higher education and working license. The regulations for them have been harmonized, primarily because of the European regulations. It is also important that the roles defined in the national regulations of these countries are in accordance with the roles stipulated in the Joint Guidelines of WHO and FIP (2011). The requirements for the pharmacist competences are mostly similar and in accordance with the GPP requirements. With respect to the requirements related to the premises, equipment and distribution in the phar- macies located in inhabited areas, there are differences in the regulations of these countries because of the differences in the priorities of the national health policies, as well as the demographic, cultural, social and economic characteristics. With respect to the services provided by the pharmacies (community and hospital), one can say that there are differences, e.g. the number of services provided in Great Britain is the biggest. Also, the pharmacies get refunded for most of these services, either from the various funds or other health insurance companies. In Slovenia and Croatia, this number is smaller, but the current regulation provides a solid basis for this number to increase. In general, the pharmaceutical profession has been comprehensively addressed and regulated in all four countries, in accordance with the requirements for minimum national requirements stated in the Joint Guidelines of WHO and FIP (2011).

With respect to the legal status of the pharmacy practice and services in the Republic of Macedonia, it is necessary to change and augment the current legislation. Primarily because of Macedonia's aspirations to enter the EU, it needs to improve the provision of healthcare by introducing new, more efficient and more accessible patient services that will contribute towards savings in the health sector. The Macedonian legislation needs to be harmonized with the European legislation and a series of Directives need to be adopted such as the Directive on Falsified Medicines (2011/62/EU), the Directive on Electronic Trading (2000/31/EC), the Directive on Application of the Rights of Patients to Cross-Border Healthcare (2011/24/EC), etc. It is necessary to enact legislative solutions that will regulate the pharmacy practice in a way that will fulfill the minimal regulation requirements, in accordance with the Joint Guidelines of WHO and FIP (2011) and the national needs of the health system and the population, with a view of providing better, more efficient, more accessible and economically more favorable healthcare.

\section{References}

Directive 2001/83/EC of the European Parliament and of the Council of 6 November 2001 on the Community code relating to medicinal products for human use. OJ L 311, 28.11.2001.

EAHP/HOPE, Hospital Pharmacies in European Union, April 2002.

FIP, Good Pharmacy Practice in developing countries; Recommendations for step-wise approach, Sept. 5, 1993, Council Meeting, Tokyo.

FIP, Standards for Quality of Pharmacy Services (in developed countries), Good Pharmacy Practice, Sept. 5, 1993, Council Meeting, Tokyo.

FIP/WHO, Annex 8: Joint FIP/WHO guidelines on good pharmacy practice: standards for quality of pharmacy services from the WHO technical report series, No. 961, 45th report of the WHO Expert Committee on specifications for pharmaceutical preparations (C) World Health Organization 2011.

German Pharmacies Act, (Gezets über das Apotenkenwesen), Federal Law Gazette 15.10.1980, as amended on 
28.09.2009.

Guillaume L, Cooper R, Avery A, Mitchell S, Ward P, Anderson C, Bissell P, Hutchinson A, James V, Lymn J, McIntosh A, Murphy E, Ratcliffe J. Supplementary prescribing by community and primary care pharmacists: an analysis of PACT data, 2004-2006. J Clin Pharm Ther 2008; 33 (1): 11-6.

Health and Social Care Act 2001, Available at: http://www. legislation.gov.uk

Health Services Act 1977, Available at: http://www.legislation. gov.uk

Health Services and Public Health Act, 1968, Available at: http:// www.legislation.gov.uk

Health Strategy of the Republic of Macedonia 2020, efficient and fair health system, (Здравствена стратегија на Република Македонија 2020, сигурен, ефикасен и правичен здравствен систем), February 2007.

Hepler CD, Strand L. 1990, Opportunities and responsibilities in pharmaceutical care. Am J Hosp Pharm; 47:533-543.

http://www.nhs.uk/NHSEngland/AboutNHSservices/ pharmacists/Pages/pharmacistsandchemists.aspx

Law on Health Insurance, (Закон за здравственото осигурување) Official Gazette of RM 25/2000 (currently amended).

Law on Health Insurance, (Zakon o zdravstvenem varstvu in zdravstvenem zavarovanju), Official Gazette of RS 76/06.

Law on Health Protection,(Zakon o zdravstveni dejavnosti,), Official Gazette of RM 43/2012.

Law on Healthcare, (Zakon o zdravstvenoj zaštiti), Official Gazette of RC 150/08, 155/09, 71/10.

Law on Healthcare, (Zakon o zdravstveni dejavnosti), Official Gazette of RS 36/04.

Law on Mandatory Health Insurance,( Zakon o obaveznoma zdravstvenom osiguranju), Official Gazette of RC 150/08.

Law on medicinal products and medical devices, (Закон за лековите и медицинските помагала), Official Gazette of RM 106/2007, 88/2010, 36/2011, 53/2011, 136/2011, $11 / 2012$.

Law on Medicines, (Zakon o ljekovima), Official Gazette of RC 45/09, 71/07.

Law on Pharmacy Practice, (Zakon o ljekarništvu), Official Gazette of RC 121/03, 117/08, 35/08

Law on Pharmacy Practice, (Zakon o lekarniški dejavnosti), Official Gazette of RS 36/04.

Medicines Act 1968, Available at: http://www.legislation.gov.uk

National Health Service Act 1977, Available at: http://www. legislation.gov.uk
Ordinance on the Operation of Pharmacies, (Apotekenbetriebbsordnung - ApBetrO),Federal Law Gazette from 15.10.1980, as amended on 28. 5. 2008.

PGEU, European Community Pharmacy Facts \& Figures, PGEU DATA BASE for 2010 and 2011 May 2012, available at: www.pgeu.eu.

Pharmacy Act 1852, Available at: http://www.legislation.gov.uk

Pharmacy Act 1954, Available at: http://www.legislation.gov.uk

Pharmacy and Poisons Act (1933), Available at: http://www. legislation.gov.uk

Pisano DJ, Essentials of Pharmacy law, CRC Press, Pharmacy education services, United States, 2003.

Prescription Only Medicine Order, 1997, Available at: http:// www.legislation.gov.uk

Rule Book on Performing the Pharmacy Practice, (Pravilnik o pogojih za opravljanje ljekarniške dejavnosti), Official Gazette of RS 36/2004.

Rule Book on the method of dispensation of prescription medicines, (Правилник за начинот на издавање на лекови на рецепт), Official Gazette of RM 106/07.

Rule Book on the content and the method of administering the rights and obligations arising from the mandatory health insurance, (Правилник за содржината и начинот на остварување на правата и обврските за задолжителното здравствено осигурување), Official Gazette of RM 111/2000, 105/2011.

Taylor, D., Mrazek, M., Mossialos, E., 2004. Regulating pharmaceutical distribution and retail pharmacy in Europe. in: Mossialos, E., Mrazek, M., Walley, T., Regulating pharmaceuticals in Europe: striving for efficiency, equity and quality. Open University Press, Maidenhead, Berkshire.

The Pharmacy Contract, PSNC, 2011, 2012 available at http:// www.psnc.org.uk/pages/introduction.html

Tonna, A.P., Stewart, D., West, B., McCaig, D., 2007. Pharmacist prescribing in the UK - a literature review of current practice and research. J. Clin. Pharm. Ther. 32, 545-556.

Treaty establishing the European Community (Consolidated text). OJ C 325/33, 24.12.2002.

Treaty of European Union. OJ C 191, 29.7.1992 (consolidated text OJ C 325, 24.12.2002).

Väänänen, M., 2008. Community pharmacies and the needs of mobile EU citizens - a study of Fins living in Spain, Doctorial dissertation, pp 13-29.

Van Mil, J.W., Schulz, M., 2006. A review of Pharmaceutical care in Community Pharmacy in Europe. Harvard Health Policy Review 7(1), 155-168. 


\title{
Резиме
}

\section{Правната положба на аптекарската дејност во Европската Унија и Република Македонија}

\author{
J. Патчева ${ }^{1 *}$, К. Младеновска², Л. Петрушевска - Този² \\ ${ }^{I}$ Фармацевтска Комора на Македонија, 50-та Дивизија 34, 1000 Скопје, Македонија \\ ${ }^{2}$ Фармацевтски Факултет, Универзитет „Св. Кирил и Методиј“, Водњанска 17, 1000 Скопје, Македонија
}

Клучни зборови: добра фармацевтска практика, стандарди, законодавство, ЕУ, Македонија

Историски гледано, може да се забележи дека улогата на фармацевтите кои работат во јавните и болничките аптеки стана покомплексна. Тие, денес не само што набавуваат, чуваат, подготвуваат и издаваат лекови со обезбеден квалитет, туку и обезбедуваат професионални услуги базирани на концептот на фармацевтска грижа и добра фармацевтска практика.

Во овој труд даден е преглед на актуелните правни акти кои го регулираат статусот и дејноста на јавните и болничките аптеки во некои земји членки на ЕУ и во Македонија. Исто така се зборува и за имплементацијата на концептот на фармацевтска грижа и добра фармацевтска практика во одредени земји како Велика Британија, Германија и Словенија, Хрватска, како идна земја членка на ЕУ, и Македонија. Во продолжение, презентиран е низ на препораки за воспоставување на стандарди за Добра фармацевтска практика. На крај, направен е обид да се воспостават основи за изработка на современ Закон за аптекарска дејност во Република Македонија. 
